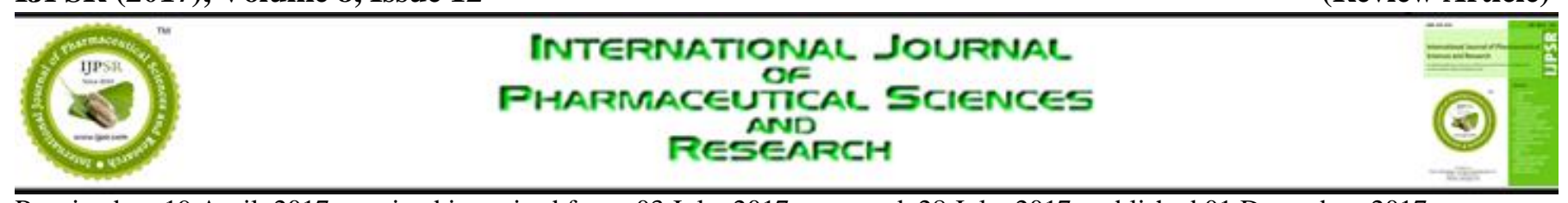

Received on 19 April, 2017; received in revised form, 03 July, 2017; accepted, 28 July, 2017; published 01 December, 2017

\title{
A COMPREHENSIVE REVIEW ON HERBAL COSMETICS
}

\author{
Rohit Kumar Bijauliya*, Shashi Alok, Mayank Kumar, Dilip Kumar Chanchal and Shrishti Yadav \\ Department of Pharmacognosy, Bundelkhand University, Jhansi - 284128, Uttar Pradesh, India.
}

Keywords:

Herbal extracts, Herbal drug, Cosmetic, Ayurveda

\section{Correspondence to Author: \\ Rohit Kumar Bijauliya}

Research Scholar, Institute of Pharmacy, Bundelkhand University, Jhansi - 284128, Uttar Pradesh, India.

E-mail: rkpharma3791@gmail.com

\begin{abstract}
India is a focus for development of Ayurveda, Unani, Siddha, Homoeopathy and another natural herbs based health science (AYUSH). Ayush Pharmaceutical industry having great possible and contingency for saundarya prasadka category (herbal cosmetic) development in future. Natural beauty is blessing and cosmetics help in presenting and increaning the beauty and personality aspects of human beings. Saundarya prasadak are the preparation, which represent cosmetic base correlate with known Ayurveda, Siddha and Unani (ASU) drugs active ingredient (which reference are readily available in schedule 1st book of Drug and cosmetic act 1940 and rule 1945). In traditional era people were used to various lepa, Alepa, Pralepa, Udavartan, Prakshalan etc for saundrya prasadan karma. Nature has offered the way to keep up that parity. Herbs! Yes herbs are one such means. An herb is a plant or plant extract, including leaves, bark, berries, roots, gums, seeds, stems and flowers which are favour with nourishing and healing elements. Cosmetics alone are not competent to take care of skin and others body parts, it requires association of active ingredients to check the casualty and ageing of the skin. Herbal cosmetics have improved much popularity among the population. Herbal cosmetics products claimed to have efficacy and intrinsic acceptability due to routine use in daily life and avoid the adverse effects which are commonly seen in synthetic products.
\end{abstract}

INTRODUCTION: The word cosmetic was derived from the Greek word "kosm tikos" meaning having the power, arrange, skill in decorating ${ }^{1}$. The origin of cosmetics forms a continuous narrative throughout the history of man as they developed. The man in prehistoric times $3000 \mathrm{BC}$ used colours for decoration to attract the animals that he wished to hunt and also the man survived attack from the enemy by colouring his skin and adorned his body for protection to provoke fear in an enemy (whether man or animal). The origin of cosmetics were associated with hunting, fighting, religion and superstition and later associated with medicine ${ }^{2}$.

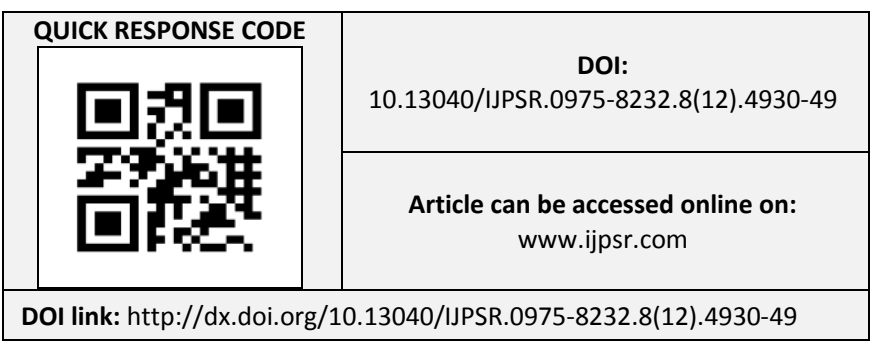

The term Cosmeceuticals was first used by Raymond Reed founding member of US Society of Cosmetics Chemist in 1961. He actually used the word to brief the active and science based cosmetics. The above term was further used by Dr. Albert Kligman in the year 1984 to refer the substances that have both cosmetic and therapeutic benefits ${ }^{3}$. Cosmeceuticals are cosmetic pharmaceutical hybrids intended to enhance health and beauty through ingredients that influence the skin's biological texture and function ${ }^{4}$.

The only factor they had to rely on was the knowledge of nature compiled in the Ayurveda. The science of Ayurveda had utilized many herbs and floras to make cosmetics for beautification and protection from external affects. The natural content in the botanicals does not cause any side effects on the human body; instead enrich the body with nutrients and other useful minerals. The cosmetics, according to the Drugs and Cosmetics Act is defined as articles intended to be rubbed, 
poured, sprinkled or sprayed on, introduced into or otherwise applied to the human body or any part for cleansing, beautifying, promoting attractiveness or altering the appearance. The cosmetic does not come under the preview of drug license ${ }^{5}$. There is common belief that chemical based cosmetics are harmful to the skin and an increased awareness among consumers for herbal products triggered the demand for natural products and natural extracts in cosmetics preparations. The increased demand for the natural product has created new avenues in cosmeceutical market. The Drug and Cosmetics Act specify that herbs and essential oils used in cosmetics must not claim to penetrate beyond the surface layers of the skin nor should have any therapeutic effect ${ }^{6}$.

Herbal cosmetics, here in after referred as products, are formulated, using various permissible cosmetic ingredients to form the base in which one or more herbal ingredients are used to provide defined cosmetic benefits only, shall be called as "Herbal Cosmetics" 7 . The history of the herbal cosmetics industry includes very dark chapters in European and Western countries from about six centuries back. Mixtures and pastes were then used to whiten the face, a practice which remained popular till over four hundred years later. The early mixtures that were used in Europe for this purpose were so potent that they often led to paralysis, strokes or death. In that era, the history of herbal cosmetics in the 1940s shows how the fashion or trend with respect to lipstick colours was changed annually, getting darker and closer to red every passing year ${ }^{8}$.

There is an extensive variety of the herbal cosmetics that are produced and commonly used for daily purposes. Herbal cosmetics like herbal conditioner, herbal soaps, herbal face wash, herbal shampoo, and many more are exceptionally acclaimed by the masses. The best thing of the herbal cosmetics is that it is purely made by the herbs and shrubs. The natural content in the herbs does not have any reactions on the human body; rather enhance the body with, supplements and other helpful minerals. Herbal cosmetics are comprised of floras like saffron (kesar), ashwagandha, sandal (chandan) and numerous increasingly that is expanded with healthy nutrients and all the various essential components. It is evaluated that roughly 400 flavours are utilized far and wide, although only about 70 spices are officially recognized. Herbs have variety of function such as food flavourings, cosmetics and medicine in the forms of tea, tablet, capsule, tincture, cream, syrup and liquid.

The worldwide herbal industry is currently evaluated to be more than US $\$ 10$ billion dollars and expanding at a rate of three to four percent annually for reasons of increased consumption in processed foods and demand for ethnic foods, natural fragrances, and innovation in beverage products. The biggest markets, regarding of manufacturing and consumption are in Europe, followed by Asia ${ }^{9}$.

Herbal medicines include herbs, herbal materials, herbal preparations and finished herbal products. In some countries herbal medicines may contain, by tradition, natural organic or inorganic active ingredients that are not of plant origin (e.g. animal and mineral materials).

Herbs include crude plant material, such as leaves, flowers, fruit, seeds, stems, wood, bark, roots, rhizomes or other plant parts, which may be entire, fragmented or powdered.

Herbal materials include, in addition to herbs, fresh juices, gums, fixed oils, essential oils, resins and dry powders of herbs. In some countries, these materials may be processed by various local procedures, such as steaming, roasting or stirbaking with honey, alcoholic beverages or other materials.

Herbal preparations are the basis for finished herbal, products and may include comminute or powdered herbal materials, or extracts, tinctures and fatty oils of herbal materials. They are produced by extraction, fractionation, purification, concentration, or other physical or biological processes. They also include preparations made by steeping or heating herbal materials in alcoholic beverages and/or honey, or in other materials.

Finished herbal products consist of herbal preparations made from one or more herbs. If more than one herb is used, the term "mixture herbal product" can also be used. Finished herbal products and mixture herbal products may contain excipients in addition to the active ingredients. 
However, finished products or mixture herbal products to which chemically defined active substances have been added, including synthetic compounds and/or isolated constituents from herbal materials, are not considered to be herbal.

Present Status: Herbalists today, believe to help people build their good health with the help of natural sources. Herbs are considered to be food rather than medicine because they're complete, allnatural and pure, as nature intended. When herbs are taken, the body starts to get cleansed, it gets purifying itself. Unlike chemically synthesized, highly concentrated drugs that may produce many side effects, herbs can effectively realign the body's defence. Herbs do not produce instant cures, but rather offer a way to put the body inpropertune with nature for thousands of years, humans have used herbs. Herbs have been used in the following ways - In cooking for flavouring foods, as perfumes, as disinfectants, to protect us against germs, as medicines to heal when we are sick ${ }^{10,11}$.

\section{Advantages of Herbal Cosmetics over Synthetic:} Herbal cosmetics are the modern trend in the field of beauty and fashion. These agents are gaining popularity as nowadays most women prefer natural products over chemicals for their personal care to enhance their beauty as these products supply the body with nutrients and enhance health and provide satisfaction as these are free from synthetic chemicals and have relatively less side-effects compared to the synthetic cosmetics ${ }^{12}$.

Following are some of the advantages of using natural cosmetics which make them a better choice over the synthetic ones:

Natural Products: The name itself suggests that herbal cosmetics are natural and free from all the harmful synthetic chemicals which otherwise may prove to be toxic to the skin. Instead of traditional synthetic products different plant parts and plant extracts are used in these products, e.g. Aloe vera gel and coconut oil. They also consist of natural nutrients like Vitamin E that keeps skin healthy, glowing and beautiful. For example, Aloe vera is a herbal plant species belonging to Liliaceae family and is naturally and easily available ${ }^{13}$. There are a rising number of consumers concerned about ingredients such as synthetic chemicals, mineral oils who demand more natural products with traceable and more natural ingredients, free from harmful chemicals and with an emphasis on the properties of botanicals ${ }^{14}$.

Safe to Use: Compared to other beauty products, natural cosmetics are safe to use. They are hypoallergenic and tested and proven by dermatologists to be safe to use anytime, anywhere. Since they are made of natural ingredients, people don't have to worry about getting skin rashes or experience skin itchiness. Example - BHA (Butylated Hydroxyanisole) and BHT (Butylated Hydroxytoluene) are closely related synthetic antioxidants and are used as preservatives in lipsticks and moisturizers 15. BHA and BHT can induce allergic reactions in the skin ${ }^{16}$. The international Agency for Research on Cancer classifies BHA as a possible human carcinogen ${ }^{17}$. Herbal cosmetics contain natural antioxidants like Vitamin $\mathrm{C}^{18}$.

Compatible with All Skin Types: Natural cosmetics are suitable for all skin types. No matter if you are dark or fair, you will find natural cosmetics like foundation, eye shadow, and lipstick which are appropriate irrespective of your skin tone. Women with oily or sensitive skin can also use them and never have to worry about degrading their skin condition.

Coal tar derived colours are used extensively in cosmetics; coal tar is recognized as a human carcinogen and the main concern with individual coal tar a colour (whether produced from coal tar or synthetically) is they can cause cancer ${ }^{19}$. But natural colours that are obtained from herbs are safer.

Wide Selection to choose From: Natural cosmetics may still be a new type in the beauty industry but they already offer a variety of beauty products for all make up crazy people out there to choose from. One will find a variety of foundation, eye shadow, lipstick, blush, mascara, concealer and many more which are all naturally formulated. Furthermore, one will find locally made natural cosmetics or those made by famous designers worldwide. There exist a large variety of herbal extracts, to name a few Andrographis paniculata (Kalmegh), Asparagus racemosus (Shatawari), Boswellia serrata (Salai Guggal), Asphalt (Shilajit) etc ${ }^{20}$. 
Fits Your Budget: Natural cosmetics are not that expensive. In fact, some of these products are more affordable than synthetic ones. They are offered at discounted prices and are sold for a cheap price during sales. Just need to survey enough to look for great deals. An estimate of WHO demonstrates about $80 \%$ of world population depends on natural products for their health care, because of side effects inflicted and rising cost of modern medicine. World Health Organization currently recommends and encourages traditional herbal cures in natural health care programs as these drugs are easily available at low cost and are comparatively safe ${ }^{21}$.

Not Tested on Animals: Some cosmetics are initially tested on animals to ensure that they are safe and effective to use for human. However, natural cosmetics need not be tested on animals. These natural formulations are tested by experts in laboratories using state of the art equipment with no animals involved ${ }^{12}$.

No Side Effects: The synthetic beauty products can irritate your skin, and cause pimples. They might block your pores and make your skin dry or oily. With natural cosmetics, one need not worry about these. The natural ingredients used assure no side effects; one can apply them anytime, anywhere. For example herbal cosmetics are free from parabens that are the most widely used preservative in cosmetics and can penetrate the skin ${ }^{22}$. And are suspected of interfering with hormone function (endocrine disruption) ${ }^{15}$.

Regulatory Status: The legal difference between a cosmetic and a drug is determined by a products intended use. Under present concept, the boundary at which a cosmetic product becomes drug is not well-defined and different laws and regulations apply to each type of product.

The drugs and cosmetic Act 1940 defines a drug and a cosmetic as; Drug- "All medicines for internal or external use of human beings or animals and all substances intended to be used for; or in the diagnosis, treatment, mitigation or prevention of any disease or disorder in humans or animals".

Cosmetic- "Any article intended to be rubbed, poured, sprinkled or sprayed on or introduced into or applied to any part of the human body for cleansing, beautifying, promoting attractiveness or altering the appearance and includes any article intended for use as a component of cosmetic" 23-24.

Some products meet the definitions of both cosmetics and drugs. This may happen when a product has more than one intended uses. For example, a shampoo is a cosmetic because its intended use is to clean the hair. An anti-dandruff shampoo is a drug because its intended use is to treat dandruff. Among the cosmetic/drug combinations are toothpastes that contain fluoride, deodorants that are antiperspirants and moisturizers with sun-protection claims. The claims made about drugs are subject to detailed analysis by the Food and Drug Administration (FDA) review and approval process, but cosmetics are not subject to mandatory FDA review. Although there is no legal category called cosmeceuticals, the term has found application to designate the products at the border line between cosmetics and pharmaceuticals ${ }^{25-26}$.

Federal Food, Drug and Cosmetic Act do not recognize the term itself. It is also often difficult for consumers to determine whether 'claims' about the actions or efficiency of cosmeceuticals are valid unless the product has been approved by the FDA or equivalent agency. Some countries have the classes of products that fall between the two categories of cosmetics and drugs: for example, Japan has 'Quasi-drugs'; Thailand has 'controlled cosmetics' and Hong Kong has 'cosmetic-type drugs'. The regulations of cosmeceuticals have not been harmonized between the USA, European, Asian and other countries 27 .

Indian Extracts for Herbal Cosmetics: Herbs play a significant role, especially in modem aimes, when the damaging effects of food processing and overmedication have assumed alarming proportions. They are now being increasingly cosmetics, foods and teas, as well as alternative medicines. The growing interest in herbs is a part of the movement towards change in life-styles. This movement is based on the belief that the plants have a vast potential for their use as a curative medicine ${ }^{28}$.

Aloe vera: is a most ingenious mixture of an antibiotic, an astringent coagulating agent, a pain inhibitor and a growth stimulator (also called a "wound hormone"), whose function is to accelerate 
the healing of injured surfaces. It is used for pain relief and healing of 'hemorrhoids, applied externally and internally it's also used for sunburn, scratch and a cleansing purge for the body or skin. It is an aid to growing new tissue and alleviating the advance of skin cancer caused by the sun ${ }^{29}$.

Amla (Embilica officinalis): Amla is the name given to the fruit of a small leafy tree (Emblica officinalis), which grows throughout India and bears an edible fruit. This fruit is highly prized both for its high Vitamin $\mathrm{C}$ content and for the precious oil, which is extracted from its seeds and pulp and used as a treatment for hair and scalp problems. It is used in eye syndromes, hair loss and children ailments etc ${ }^{29}$.

Brahmi (Bacopa monnoria): Reetha powder is prepared from dried fruit of Reetha. It can be used as a face pack to improve facial complexion. It is used as a hair application to make hair shiny and their beautification. It also removes dandruff and lice in hair. It can also be used to clean jewellery and washing woolen clothes. It is used in Ayurvedic preparations and Herbal Shampoos ${ }^{29}$.

Multani Mitts (Fullers Earth): It is Mother Nature's own baby powder. Clay was one of the earliest substances to be used as a beauty mask to draw oils from the skin, natural moisturizers for hairs, teeth, gums and hair. To remove pimple marks, treating sunburn, helps unclog pores, to cleanse the skin of flakes and dirt ${ }^{29}$.

\section{Neem (Azadirachata indica) "Sarva Roga} Nivarini: the curer of all ailments" Neem's role as a wonder drug is stressed as far back as 4500 years ago. Some of its health restoring benefits Effective in skin infection, rashes and pimples, immunity booster, anti obesity, blood purifier for beautiful and healthy skin, anti diabetic, anti viral, dispels intestinal worms and parasites, malaria, piles, hair disorder and oral disorders ${ }^{29}$.

Shikaka (Acasia cancina): Acasia concinna is a small shrub-like tree, which grows in the warm, dry plains of central India. For centuries the people who have had access to this tree have used its podlike fruit to clean their hair. It's considered a superior cleanser for "lustrous long hair" and has been reported as "promoting hair growth and preventing dandruff. It also helps in removing dandruff and lice and very effective in removing oil and dirt from hair ${ }^{29}$.

\section{Herbal Medicines for Treatment of Various Ailments: \\ Dry Skin Treatment:}

Aloe vera: A native of southern Africa, the Aloe vera plant has fleshy spiny-toothed leaves and red or yellow flowers. It is an ingredient in many cosmetics because it heals moisturizes, and softens skin. Simply cut one of the Aloe vera leaves to easily extract the soothing gel. Aloe vera contains amino acids like leucine, isoleucine, saponin glycosides that provide cleansing action, Vitamins A, C, E, B, choline, $\mathrm{B}_{12}$ and folic acid and provide antioxidant activity ${ }^{30}$.

Coconut Oil: It is produced by crushing copra, the dried kernel, which contains about $60-65 \%$ of the oil. Coconut oil contains a high amount of glycerides of lower chain fatty acids. Coconut oil is derived from the fruit or seed of the coconut palm tree Cocos nucifera, family Arecaceae. The melting point of coconut oil is 24 to $25^{\circ} \mathrm{C}\left(75-76^{\circ} \mathrm{F}\right)$ and thus can be used easily in liquid or solid forms and is often used in cooking and baking. Coconut oil is excellent as a skin moisturizer and softener ${ }^{32}$.

Jojoba Oil: It is a mixture of long chain, linear liquid wax esters extracted from the seeds of the desert shrub Simmondsia chinenesis, family Simmondsiaceae. Jojoba oil is easily refined to remove any odour, colour it is oxidatively stable, and is often used in cosmetics as a moisturizer and as carrier oil for exotic fragrances. Human sebum and jojoba oil are virtually identical. Sebum protects and moisturizes the skin and hair but is stripped away by chemicals, pollutants, sun and the aging process, resulting in dry skin and hair. Jojoba oil replenishes what skin and hair lose and restores them to their natural $\mathrm{pH}$ balance ${ }^{31}$.

Olive Oil: This oil is a fixed oil extracted from the fruits of Olea europaea, family oleaceae. The major constituents are triolein, tripalmitin, trilinolein, tristearate, monosterate, triarachidin, squalene, $\beta$ sitosterol and tocopherol. It is used as skin and hair conditioner in cosmetics like lotions, shampoos etc. It is a potent fatty acid penetration enhancer ${ }^{31}$.

Sunflower Oil: It is the non-volatile oil extracted from sunflower seeds obtained from Helianthus 
annuus, family Asteraceae. Sunflower oil contains lecithin, tocopherols, carotenoids and waxes. It has smoothing properties and is considered noncomedogenic ${ }^{32}$.

Simple yet cost-effective oil, well tried and tested for generations in a wide variety of emulsions formulated for face and body products ${ }^{33}$.

\section{Skin Protection:}

Green tea: The tea plant has been cultivated in Asia for thousands of years ${ }^{34}$. Green tea is tea made solely with the leaves of Camellia sinensis belonging to family Theaceae ${ }^{35}$. The 4 major polyphenolic catechins present in green tea leaves are (2)-epicatechin (EC), EGC, (2)-EC-3-gallate, and EGCG, which is the most abundant ${ }^{36,37}$.

It was found that green tea extracts or an individual green tea polyphenol (GTPP), especially epigallocatechin (EGC)-3-gallate (EGCG), inhibited two-stage chemical carcinogenesis (e.g, induced by 7,12-di-methylbenz(a)anthracene [DMBA] and 12O-tetra decanoylphorbol 13-acetate [TPA]) and photo-carcinogenesis (induced by UVB) ${ }^{38}$. It is a premiere skin protectant. It protects against direct damage to the cell and moderates inflammation. The catechins in green tea are some 20 times stronger in their antioxidant powers than even Vitamin $\mathrm{E}^{35}$.

Calendula: Calendula officinalis is reported to have a remarkable antioxidant activity, antiinflammatory activity and wound healing activity 39. A previous study demonstrated that the essential oil of Calendula consists mainly of $\alpha$-thujene, $\alpha$ pinene, 1,8-Cineole, dihydrotagetone and $\mathrm{T}$ muurolol ${ }^{40}$. Calendula in suspension or in tincture is used topically to treat acne, reducing inflammation, controlling bleeding and soothing irritated tissue ${ }^{35}$. There is "limited evidence" that calendula cream or ointment is effective in treating radiation dermatitis ${ }^{41}$.

Turmeric: Turmeric is used in many celebrations of Hindus. Especially in Hindu wedding brides would rub with turmeric on their bodies for glowing look. New born babies also rubbed with turmeric on their forehead for good luck. Traditionally women rub turmeric on their cheeks to produce a natural golden glow ${ }^{42}$. It is a deep yellow-to-orange powder that comes reduce the number of Ultraviolet B (UVB)-induced sunburn cells in mice ${ }^{43}$.

\section{Anti-aging Treatment:}

Carrot: It is obtained from the plant Daucus carota belonging to family Apiaceae. It is a valuable herb since ages as due to its richness in Vitamin A along with other essential Vitamins. Carrot seed oil is used as anti-aging, revitalizing and rejuvenating agent ${ }^{32}$. The carrot gets its characteristic and bright orange colour from $\beta$ carotene, and lesser mamounts of $\alpha$-carotene and $\gamma$ carotene. $\alpha$ and $\beta$-carotenes are partly metabolized into Vitamin A in humans ${ }^{44}$.

Ginkgo: It comes from the ginkgo tree, Ginkgo biloba belongs to family Ginkgoaceae. It is best known, as a circulatory tonic, in particular for strengthening the tiny little capillaries to all the organs, but especially to the brain. The capillaries become more flexible and as a result more oxygen is delivered to the brain and eyes (to protect against degenerativeeye diseases like macular degeneration), as important as we age ${ }^{32}$.

In China and Japan, the leaves and nuts of the Ginkgo biloba (G. biloba) tree have been used for thousands of years to treat various medical conditions, including poor blood circulation; hypertension; poor memory, and depression, particularly among the elderly; male impotence. In addition, it is gaining a similar reputation as an antioxidant and anti-inflammatory agent ${ }^{45}$. The $G$. biloba extract EGb 761, prepared from the tree's leaves, is a natural mixture containing flavone glycosides (33\%), mostly quercetin and kaempferol derivatives, and terpenes $(6 \%)$, which has exhibited the capacity to isolated from the leaves of Lawsonia inermis has shown significant antifungal antibiotic effect ${ }^{46}$.

Rhodiola rosea: It is commonly known as golden root, roseroot, Aaron's rod, arctic root, king's crown, Lignum rhodium, orpin rose. It is a plant in the Crassulaceae family that habitats in cold regions of the world. It grows mainly in dry sandy ground at high altitudes in the arctic areas of Europe and Asia, traditional folk medicine used $R$. rosea to increase physical endurance, work productivity, longevity, resistance to high altitude sickness, and to treat fatigue, depression, anemia, 
impotence, gastrointestinal ailments, infections, and nervous system disorders ${ }^{47} . R$. rosea is rich in phenolic compounds, known to have strong antioxidant properties ${ }^{48}$.

Dandruff Treatment: Ayurveda has numerous natural medications wherein the most common herbs include neem, kapoor (naphthalene) and henna, hirda, behada and amalaki, magic nut, bringaraj, rosary pea, sweet flag, cashmere tree and mandor $^{32}$.

Henna: Henna comes from the plant Lawsonia inermis family Lythraceae, which contain a dye molecule called lawsone, which when processed produces Henna powder. Besides lawsone other constituents present are gallic acid, glucose, mannitol, fats, resin (2\%), mucilage and traces of an alkaloid. Leaves yield hennatannic acid and an olive oil green resin, soluble in ether and alcohol ${ }^{49}$. Lawsone edible fruit. It is highly praised both for its high Vitamin $\mathrm{C}$ content and for the precious oil, which is extracted from its seeds and pulp and used as a treatment for hair and scalp problems. It is used in eye syndromes, hair loss, and children ailments etc ${ }^{50}$.

Neem: The herb, Azadirachta indica, family Meliaceae has been found to have the properties of a Blood purifier, beauty enhancer. The common treatment for the dandruff. Neem as it produces antifungal, antibacterial, pain-relieving, and anticompounds that would treat dandruff ${ }^{51}$.

Shikakai: Acacia concinna Linn. (Leguminosae) is a medicinal plant that grows in tropical rainforests of Southern Asia. The fruits of this plant are used for washing hair, for improving hair growth, as an expectorant, emetic, and purgative. The powder of Acacia concinna Linn. shows the presence of saponins, alkaloid, sugar, tannin, flavanoids, anthraquinone glycosides ${ }^{52}$.

Hair Care: Various oils derived from vegetable and mineral sources, and are used in cosmetics. Examples of vegetables oils are almond oil, arachis oil, castor oil, olive oil, and coconut oil. Examples of mineral oils are Light and Heavy paraffin.

a) Amla: Amla is obtained from the plant Emblica officinalis, Family Euphorbiaceae. Amla is rich in Vitamin C, tannins and minerals such as phosphorus, iron and calcium which provides nutrition to hair and also causes darkening of hair 42 . Hibiscus consists of calcium, phosphorus, iron, Vitamin $\mathrm{B}_{1}$, Riboflavin, Niacin and Vitamin $\mathrm{C}$, used to stimulate thicker hair growth and prevents premature graying of hair.

b) Coconut Oil: This oil obtained from the dried solid part of the endospasm of the coconut- Cocos nucifera, family Palmea. It is white or pearl- white unctuous mass in winter and colourless in summer.

c) Almond Oil: The almond oil is obtained from Prunus dulcis. It proves to be very nourishing, and softens and strengthens the hair. The almond oil also proves to be a very good cleansing agent.

d) Arachis Oil: This is also a fixed oil obtained from the seeds of the Arachis hypogea belonging to the family Leguminoseae. The oil is pale yellow in colour, with a faint nutty odour. It is used in the preparation of hair oils and 'Brilliantines'.

e) Castor Oil: This oil is obtained from the seeds of Ricinus communis belonging to the family, Euphorbiaceae. It is used as an emollient, in the preparation of lipstick, hair oils, creams and lotions.

f) Eucalyptus Oil: Eucalyptus oil is the generic name for distilled oil from the leaf of Eucalyptus, a genus of the Plant family Myrtaceae. Eucalyptus oil can help to get rid of dandruff, which in turn can help to promote healthy growth of hair.

g) Rose Oil: The well-known essential oil is probably rose oil, produced from the petals of Rosa damascena and Rosa centifolia, family Rosaceae. Steam-distilled rose oil is known as "rose otto" while the solvent extracted product is known as "rose absolute". It is used more commonly in perfumery. The key flavour compounds that contribute to the distinctive scent of rose oil are beta-damascenone, beta-damascone, beta-ionone, and oxide.

h) Citronella Oil: It is one of the essential oils obtained from the leaves and stems of different species of Cymbopogon family Cardiopteridaceae. The crisp, rich citrus or lemon like aroma of this oil drives away body odour and is used deodorants and body sprays, although in very small quantities, since it heavy doses it may give skin irritations. It 
can also be mixed with the bathing water to have a refreshing, body odour ending bath.

i) Olive Oil: This oil is a fixed oil extracted from the fruits of Olea europaea, family oleaceae. The major constituents are triolein, tripalmitin, trilinolein, tristearate, monosterate, triarachidin, squalene, $\beta$ sitosterol and tocopherol. It is used as skin and hair conditioner in cosmetics like lotions, shampoos etc. It is a potent fatty acid penetration enhancer.

j) Sunflower Oil: It is the non-volatile oil extracted from sunflower seeds obtained from Helianthus annuus, family Asteraceae. Sunflower oil contains lecithin, tocopherols, carotenoids and waxes. It has smoothing properties and is considered noncomedogenic ${ }^{53}$. A simple yet cost-effective oil, well tried and tested for generations in a wide variety of emulsions formulated for face and body Products ${ }^{54}$.

k) Light Liquid Paraffin: It consists of a mixture of hydrocarbons in the form of an oily liquid which has no colour or odour. It is used in the manufacture of bath oils, hair oils, lotions and creams, due to its better spreadibility.

l) Heavy Liquid Paraffin: It is composed of a mixture of hydrocarbons in the form of a colourless and odourless oily liquid. Due to its soothing effect on the skin, it is used in the creams, lotions and in hair oil.

m) Waxes: They are the esters resulting from the condensation of high molecular straight chain fatty acids with high molecular straight chain monohydric alcohol of the methanol series. They are used in cosmatics as a base, along with oils and fats. Examples: lipstick.

n) Beeswax: It is a purified wax separated from the honeycomb of bees, Apis mellifera which belong to the family, Apidae. Beeswax is composed of $70 \%$ ester myricyl palmitate. Beeswax helps in the incorporation of water to form an emulsion ${ }^{55}$.

Antioxidants: Antioxidants either synthetic or natural can be effective in preventing free radical formation by scavenging them or promoting their decomposition and suppressing such disorders ${ }^{54}$. Currently, there is a growing interest toward natural antioxidants of herbal resources 55 .

Tamarind: Tamarind or Tamarindus indica L. of the Fabaceae, subfamily Caesalpinioideae consists of amino acids, fatty acids and minerals of tamarind plant parts. The most distinguished characteristic of tamarind is its sweet acidic taste due to tartaric acid. Besides being a rich source of sugars, tamarind fruit is also an excellent source of Vitamin B and contain minerals, exhibit high antioxidant capacity that appear to be associated with a high phenolic content, and thus can be an important food source ${ }^{56-60}$.

Vitamin C: Vitamin $C$ is necessary for the hydroxylation of proline, procollagen, and lysine. Vitamin $\mathrm{C}$ improves the changes caused by photo damage. Vitamin $\mathrm{C}$ has been used effectively to stimulate collagen repair, thus removing some of the effects of photo-aging on skin.

Vitamin E: (Alpha-tocopherol) is the major lipophilic antioxidant in plasma membranes and tissues. The term Vitamin E collectively refers to 30 naturally occurring molecules (4 tocopherols and 4 tocotrienols), all of which exhibit Vitamin E activity.

Its major role is generally considered to be the arrest of chain propagation and lipid peroxidation by scavenging lipid peroxyl radicals, hence protecting the cell membrane from destruction ${ }^{61}$.

\section{TABLE 1: LIST OF PLANT USED FOR SKIN CARE}

\begin{tabular}{cccccc}
\hline $\begin{array}{c}\text { S. } \\
\text { no. }\end{array}$ & $\begin{array}{c}\text { Common } \\
\text { name }\end{array}$ & $\begin{array}{c}\text { Plant name } / \\
\text { Family }\end{array}$ & $\begin{array}{c}\text { Chemical } \\
\text { constituent }\end{array}$ & Reference \\
\hline 1. & Aam & $\begin{array}{c}\text { Mangifera indica } \\
\text { Anacardiaceae }\end{array}$ & $\begin{array}{c}\text { Mangiferin, isomangiferin, } \\
\text { tannins, gallic acid } \\
\text { protocatechic acid, catechin, } \\
\text { mangiferin, alanine, glycine, } \\
\text {-aminobutyric acid, kinic } \\
\text { acid, shikimic acid. } \\
\text { Monoterpene hydrocarbons, } \\
\text { sabinene, } \alpha \text {-pinene and }\end{array}$ & $\begin{array}{c}\text { Plant extract possesses anti- } \\
\text { oxidant properties }\end{array}$ & Whole plant extract is useful \\
in skin creams to control skin & 63,63 \\
\hline
\end{tabular}




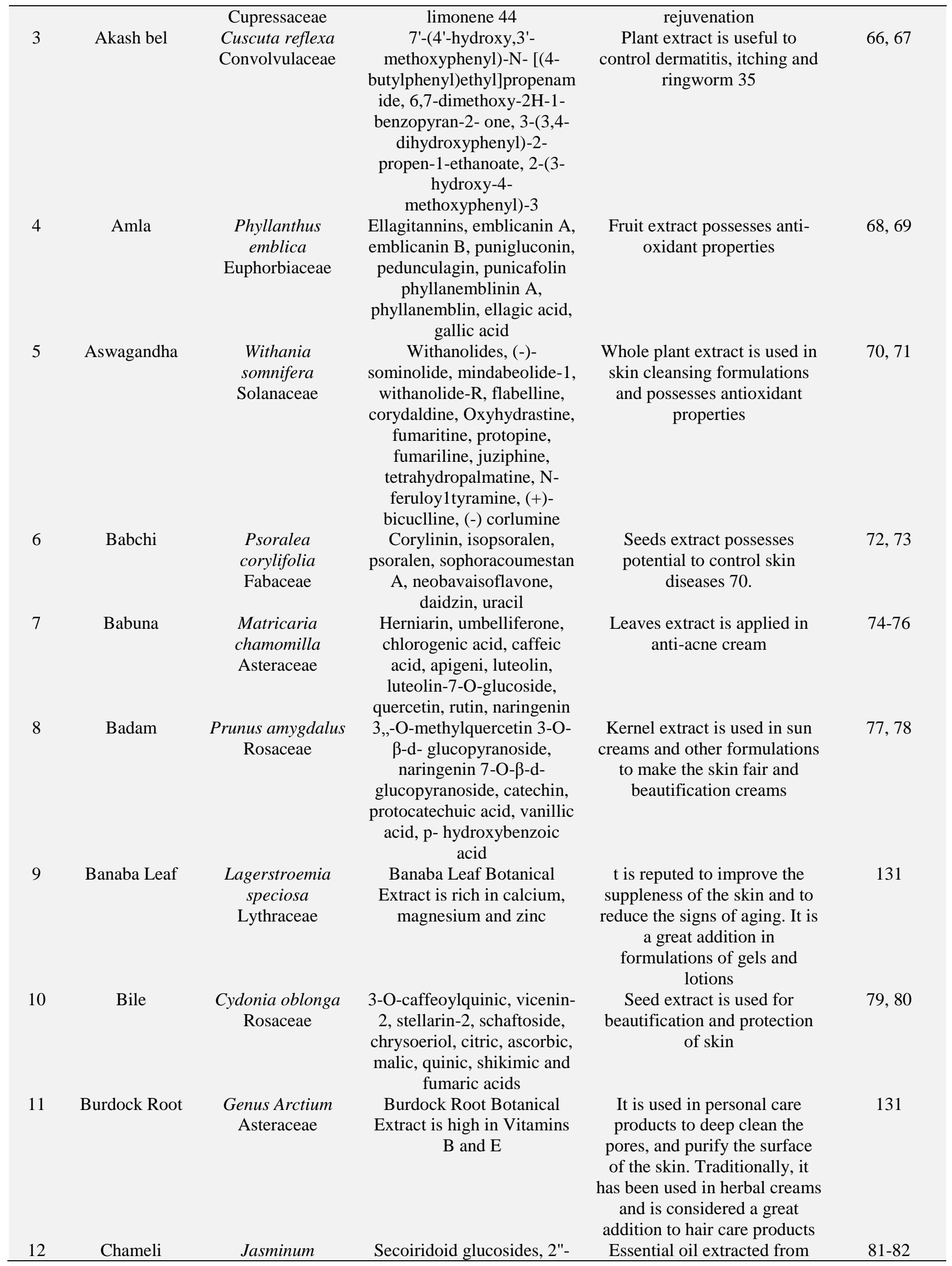




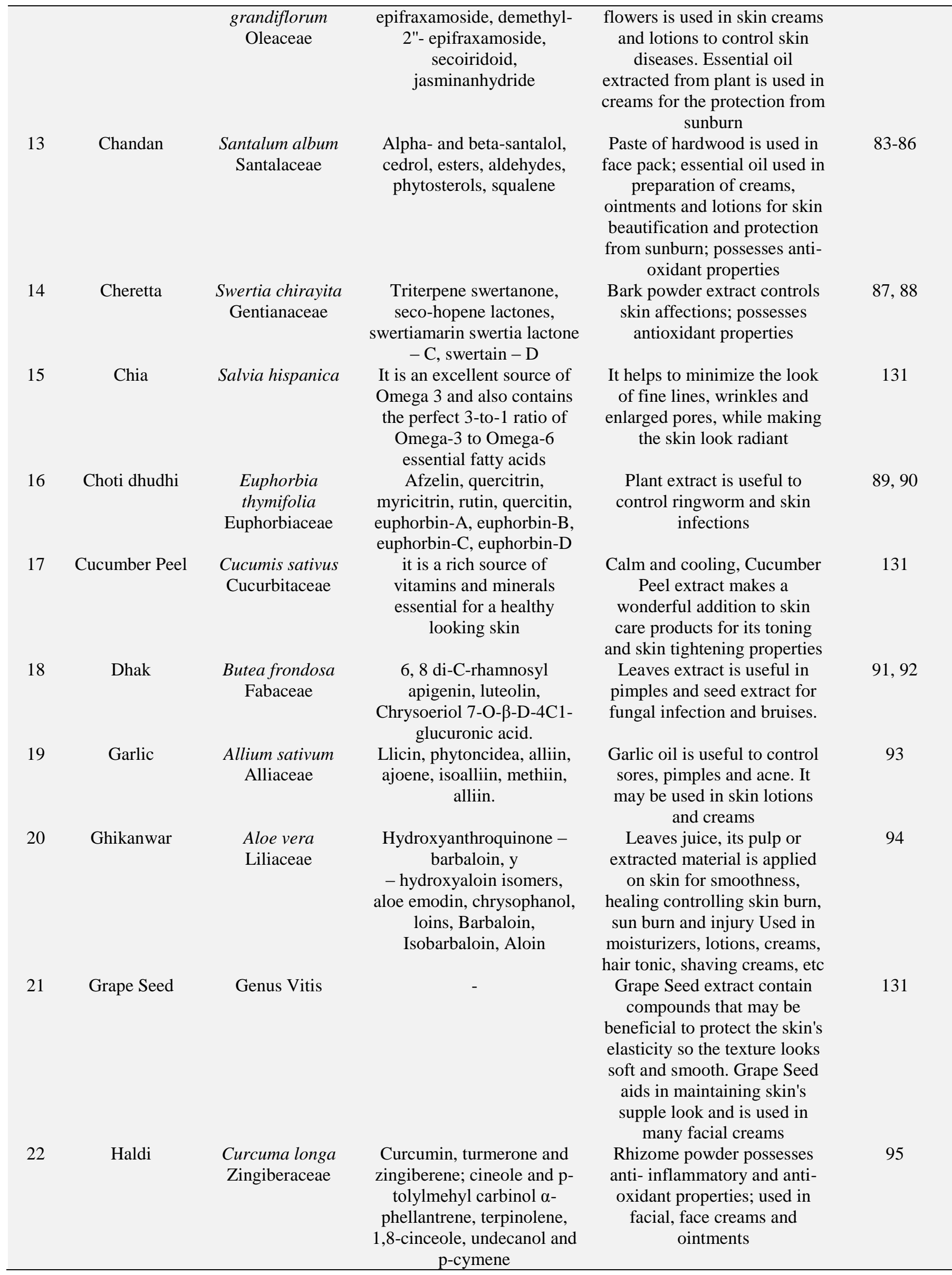




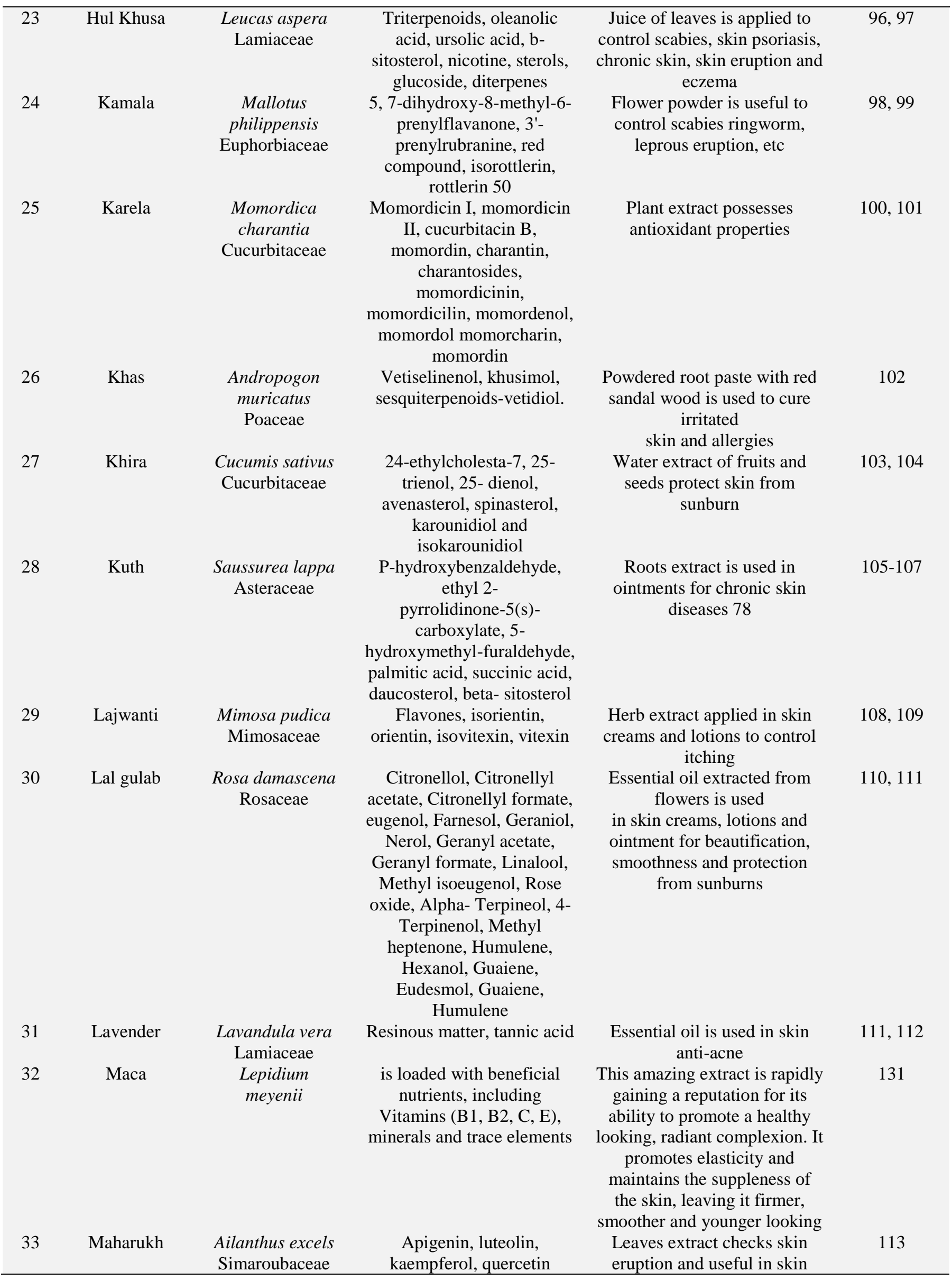




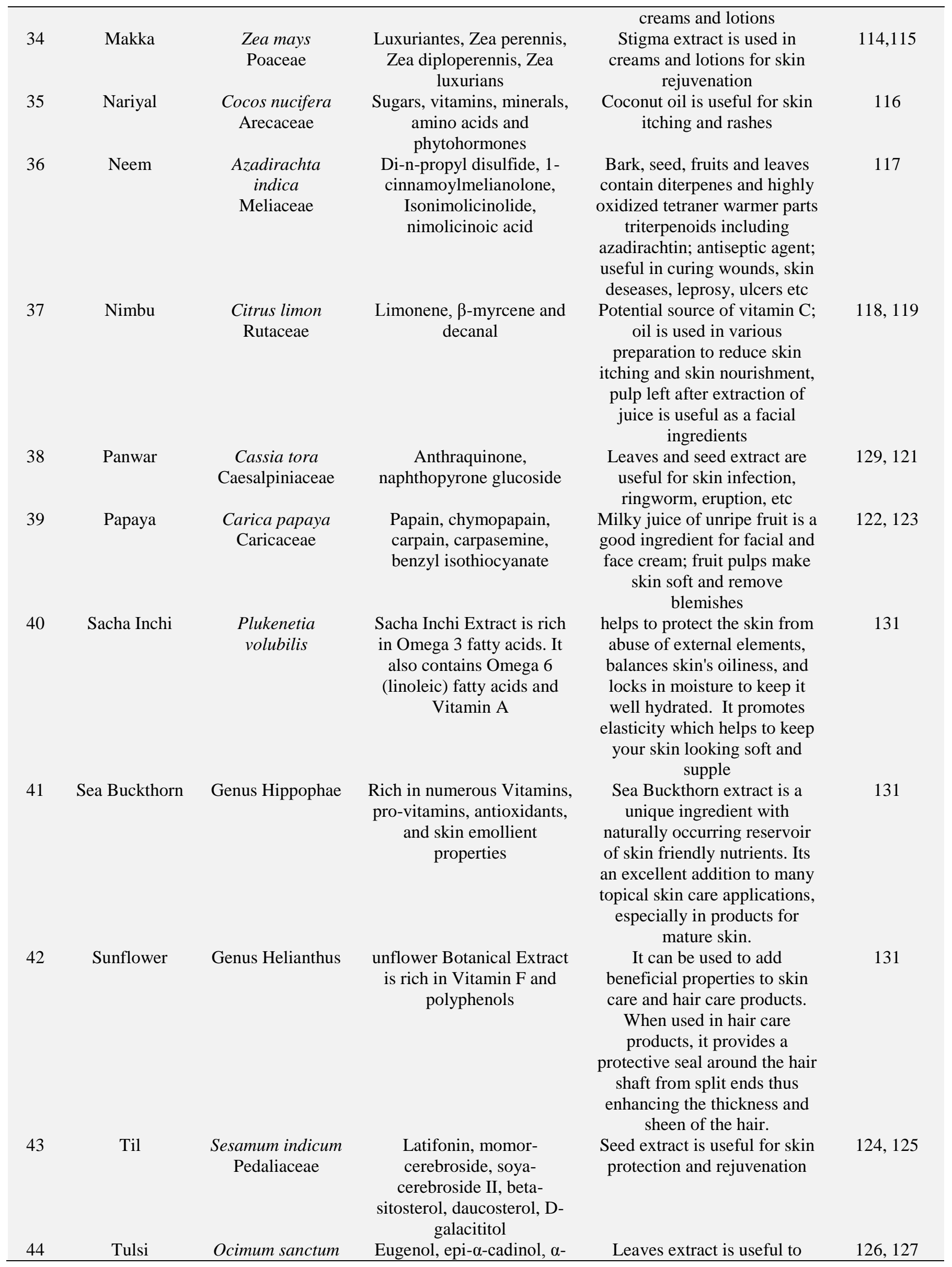




\begin{tabular}{|c|c|c|c|c|c|}
\hline & & Lamiaceae & bergamotene, $\gamma$-cadinene & $\begin{array}{l}\text { control skin infection and } \\
\text { reiuvenation }\end{array}$ & \\
\hline 45 & Water lettuce & $\begin{array}{c}\text { Pistia stratiotes } \\
\text { Araceae }\end{array}$ & $\begin{array}{l}\text { palmitic acids, anthocyanin- } \\
\text { cynidin-3-glucoside, } \\
\text { luteolin-7-glycosid, vitexin, } \\
\text { orientin }\end{array}$ & $\begin{array}{l}\text { Leaves extract is applied to } \\
\text { control chronic skin disorders }\end{array}$ & 128,129 \\
\hline 46 & Vasaca & $\begin{array}{l}\text { Adhatoda vasica } \\
\text { Acanthaceae }\end{array}$ & $\begin{array}{c}\text { Vasicine, vasicine acetate, } \\
\text { 2-acetyl benzyl amine, } \\
\text { vasicinone, quinazoline }\end{array}$ & $\begin{array}{c}\text { Fresh leaves juice / extract is } \\
\text { used for skin affection and } \\
\text { control of scabies }\end{array}$ & 130 \\
\hline
\end{tabular}

TABLE 2: LIST OF PLANT USED FOR HAIR CARE

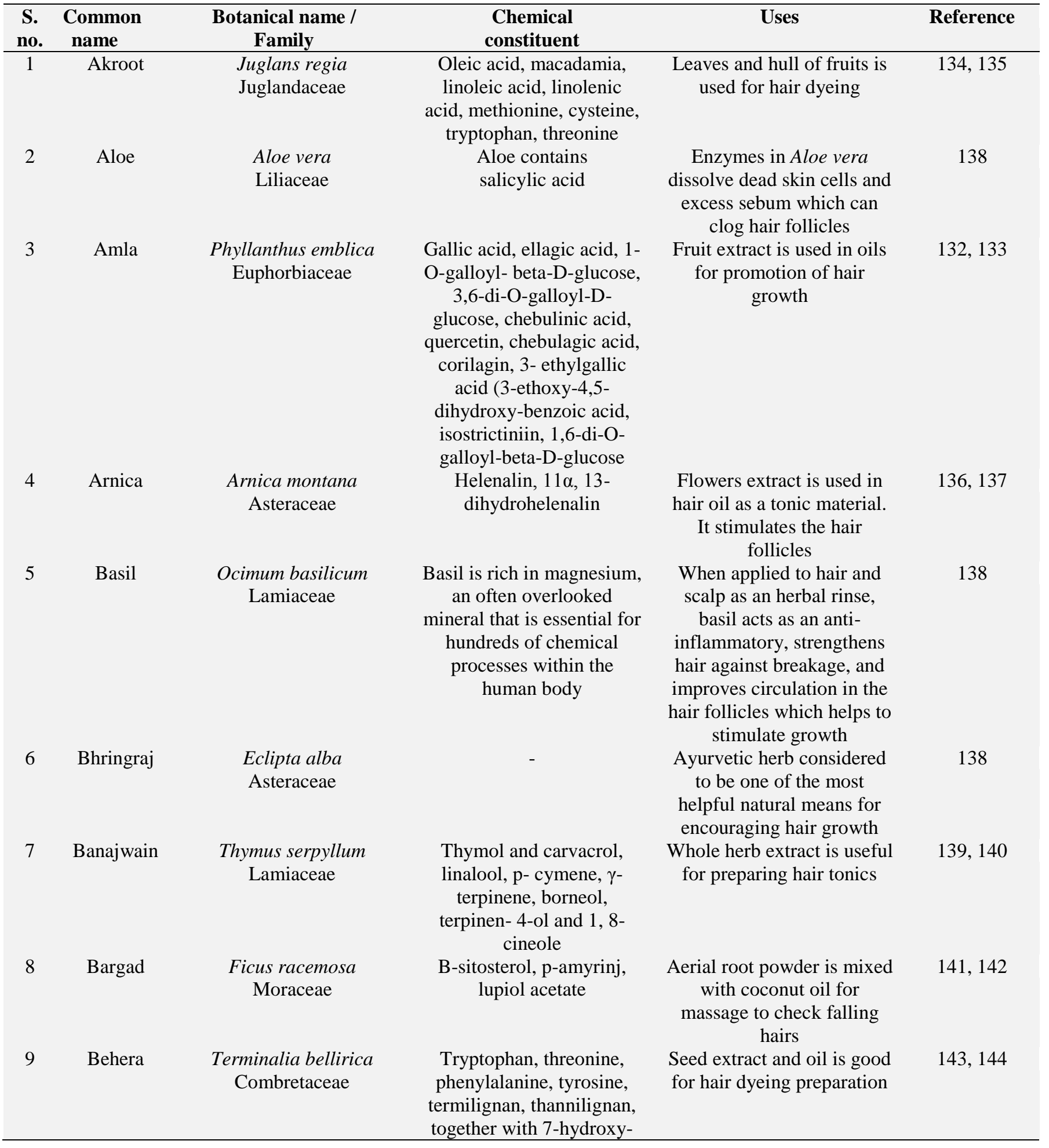




\begin{tabular}{|c|c|c|c|c|c|}
\hline & & & $\begin{array}{l}3,, 4,,- \text { (methylenedioxy) } \\
\text { flavan, anolignan B }\end{array}$ & & \\
\hline 10 & Birch & $\begin{array}{l}\text { Betula pendula } \\
\text { Betulaceae }\end{array}$ & $\begin{array}{l}\text { Carotenoid, Rubisco, } \\
\text { uronic acids, lignin }\end{array}$ & $\begin{array}{c}\text { Extract of leaves is used as } \\
\text { anti- dandruff }\end{array}$ & 145,146 \\
\hline 11 & brahmi & $\begin{array}{l}\text { Centella asiatica } \\
\text { Apiaceae }\end{array}$ & - & $\begin{array}{l}\text { Mix brahmi extract with } \\
\text { olive oil and massage into } \\
\text { the scalp to improve } \\
\text { circulation and promote } \\
\text { stronger hair growth }\end{array}$ & 138 \\
\hline 12 & Ginger & $\begin{array}{c}\text { Zingiber officinale } \\
\text { Zingiberaceae }\end{array}$ & - & $\begin{array}{l}\text { Ginger root oil increases } \\
\text { circulation in hair follicles, } \\
\text { promoting stronger and } \\
\text { faster growth }\end{array}$ & 138 \\
\hline 13 & Harra & $\begin{array}{c}\text { Terminalia chebula } \\
\text { Combretaceae }\end{array}$ & $\begin{array}{l}\text { Arjunolic acid; terminolic } \\
\text { acid; chebuloside I, II; } \\
\text { triterpenoids; triterpenoid } \\
\text { glycosides }\end{array}$ & $\begin{array}{l}\text { Seed extract is used in hair } \\
\text { care formulations }\end{array}$ & 147 \\
\hline 14 & Henna & $\begin{array}{l}\text { Lawsonia inermis } \\
\text { Lythraceae }\end{array}$ & $\begin{array}{c}\text { Lalioside, lawsoniaside, } \\
\text { uteolin-7-O- } \beta \text { - d- } \\
\text { glucopyranoside, } \\
\text { awsonicin, lawsonadeem, } \\
\text { vomifoliol }\end{array}$ & $\begin{array}{c}\text { Leaves paste is used for hair } \\
\text { dyeing and nourishment }\end{array}$ & $148-150$ \\
\hline 15 & Jatamansi & $\begin{array}{c}\text { Nardostachys jatamansi } \\
\text { Valerianaceae }\end{array}$ & $\begin{array}{c}\beta \text {-eudesmol, elemol, } \beta \text { - } \\
\text { sitosterol, angelicin, } \\
\text { jatamansinol, } \\
\text { nardostachysin }\end{array}$ & $\begin{array}{c}\text { Extract of rhizome is used } \\
\text { in hair tonics for their } \\
\text { growth }\end{array}$ & $151-152$ \\
\hline 16 & Kuth & $\begin{array}{l}\text { Saussurea lappa } \\
\text { C.B. Asteraceae }\end{array}$ & $\begin{array}{c}\text { P-hydroxybenzaldehyde, } \\
\text { ethyl 2- } \\
\text { pyrrolidinone-5(s)- } \\
\text { carboxylate, 5- } \\
\text { hydroxymethyl- } \\
\text { furaldehyde, palmitic acid, } \\
\text { succinic acid, glucose, } \\
\text { daucosterol, beta-sitosterol }\end{array}$ & $\begin{array}{c}\text { Roots extract is used in hair } \\
\text { dyeing }\end{array}$ & $153-155$ \\
\hline 17 & Lavender & $\begin{array}{l}\text { Lavandula } \\
\text { augustifolia }\end{array}$ & - & $\begin{array}{l}\text { Lavender oil stimulates } \\
\text { circulation in the scalp, } \\
\text { strengthens new hair } \\
\text { growth, and helps to } \\
\text { balance the natural oil } \\
\text { production of the scalp, } \\
\text { making it a popular choice } \\
\text { for people of all skin types }\end{array}$ & 138 \\
\hline 18 & Marigold & $\begin{array}{l}\text { Calendula } \\
\text { officinalis } \\
\text { Asteraceae }\end{array}$ & $\begin{array}{c}\alpha \text {-cadinol, T-muurolol, a- } \\
\text { thujene, dcadinene, a- } \\
\text { thujene, d-cadinene, } \mathrm{d} \text { - } \\
\text { cadinene }\end{array}$ & $\begin{array}{l}\text { Flowers extract is used in } \\
\text { hair creams for } \\
\text { smoothening effect }\end{array}$ & 156,157 \\
\hline 19 & Mustard & $\begin{array}{l}\text { Brassica spp. } \\
\text { Brassicaceae }\end{array}$ & $\begin{array}{c}\text { Quercetin, predominate, } \\
\text { kaempferol, luteolin, } \\
\text { apigenin indole-3-carbinol }\end{array}$ & $\begin{array}{c}\text { Seed oil is used as hair oil } \\
\text { and useful for hair } \\
\text { nourishment }\end{array}$ & 158,159 \\
\hline 20 & Nariyal & $\begin{array}{c}\text { Cocos nucifera } \\
\text { Arecaceae }\end{array}$ & $\begin{array}{l}\text { Minerals, Vitamins, dietary } \\
\text { fibres, sugars, organic } \\
\text { acids, fatty acid and amino } \\
\text { acid, } \alpha \text {-Tocopherol, citric, } \\
\text { malic acids }\end{array}$ & $\begin{array}{l}\text { Kernel oil is well- } \\
\text { established hair oil, which } \\
\text { is used as such or as a basic } \\
\text { raw material for preparing } \\
\text { hair oils and tonics }\end{array}$ & 160,161 \\
\hline 21 & Peppermint & $\begin{array}{c}\text { Mentha piperita } \\
\text { Lamiaceae }\end{array}$ & - & $\begin{array}{c}\text { peppermint oil as a healing } \\
\text { scalp treatment }\end{array}$ & 138 \\
\hline 22 & Ritha & $\begin{array}{l}\text { Sapindus mukorossi } \\
\text { Sapindaceae }\end{array}$ & $\begin{array}{c}\text { Saponins, sugars and } \\
\text { mucilages }\end{array}$ & $\begin{array}{l}\text { Extract of fruit coat works } \\
\text { as natural shampoo: used in } \\
\text { herbal shampoo as hair } \\
\text { cleanser }\end{array}$ & 162,163 \\
\hline
\end{tabular}




\begin{tabular}{|c|c|c|c|c|c|}
\hline 23 & Safflower & $\begin{array}{c}\text { Carthamus tinctorius } \\
\text { Asteracea }\end{array}$ & $\begin{array}{c}\text { Benzyl-O- } \beta \text {-D- } \\
\text { glucopyranoside, } \\
\text { syringarenol, lirioresinol- } \\
\text { A, } \beta \text { - sitosterol, } \\
\text { stigmasterol }\end{array}$ & $\begin{array}{c}\text { Alcoholic extract is used in } \\
\text { hair tonics }\end{array}$ & 164,165 \\
\hline 24 & Sage & $\begin{array}{l}\text { Salvia officinalis } \\
\quad \text { Lamiaceae }\end{array}$ & $\begin{array}{l}\text { Alpha-thujone, camphor } \\
\text { and viridiflorol. Carnosol, } \\
\text { rosmanol, epirosmanol, } \\
\text { isorosmanol, galdosol, and } \\
\text { carnosic acid }\end{array}$ & $\begin{array}{l}\text { Aqueous extract is used as } \\
\text { hair conditioner }\end{array}$ & $166-168$ \\
\hline 25 & Shikakai & $\begin{array}{l}\text { Acacia concinna } \\
\text { Mimosaceae }\end{array}$ & $\begin{array}{l}\text { Lupeol, spinasterol, } \\
\text { lactone, hexacosanol, } \\
\text { spinasterone, calyctomine, } \\
\text { racimase-A oleanolic acid, } \\
\text { lupenone, betulin, betulinic } \\
\text { acid, betulonic acid }\end{array}$ & $\begin{array}{l}\text { Pods extract is used as hair } \\
\text { cleanser and for control of } \\
\text { dandruff }\end{array}$ & 169,170 \\
\hline 26 & Til & $\begin{array}{l}\text { Sesamum indicum } \\
\text { Pedaliaceae }\end{array}$ & $\begin{array}{l}\text { Latifonin, momor- } \\
\text { cerebroside, soya- } \\
\text { cerebroside II, benzyl } \\
\text { alcohol-O-(2'-O- beta-D- } \\
\text { xylopyranosyl, 3'-O-beta- } \\
\text { D- glucopyranoside)-beta- } \\
\text { D- glucopyranoside, beta- } \\
\text { sitosterol, daucosterol, D- } \\
\text { galacititol }\end{array}$ & $\begin{array}{l}\text { Seed oil is one of the major } \\
\text { sources of hair oils, which } \\
\text { is used as such or a base for } \\
\text { preparing specific hair oils }\end{array}$ & $171-172$ \\
\hline 27 & Watercress & Nasturtium officianale & $\begin{array}{c}\text { watercress is richly packed } \\
\text { with Vitamins and } \\
\text { minerals }\end{array}$ & $\begin{array}{c}\text { It has proven benefits for } \\
\text { skin health and stronger } \\
\text { hair growth }\end{array}$ & 138 \\
\hline
\end{tabular}

CONCLUSION: In India more than $70 \%$ of the populations use herbal cosmetics for their health care. A present time herbal cosmetic has been marked up in personal care system and there is a great requirement for the herbal cosmetics in daily life. Healthy teeth, shiny hair and glowing skin are significant for the good looking of the human body. Herbal cosmetics are prepared, using cosmetic ingredients to form the base in which one and another herbal ingredients are used to treat different skin ailments and for the beautification. The chemical formulation of all these cosmetic products includes addition of various natural additives like waxes, oils natural colour, natural fragrances and parts of plants like leaves, etc.

The Cosmeceuticals are agents that lie elsewhere between pure cosmetics (lipstick and rouge) and pure drug (antibiotics, corticosteroids) methods. Corrective formulation based natural beauty preparation, which has cosmetic value or safe additive properties in replacing synthetic ingredient. There is need to do more $\mathrm{R}$ and $\mathrm{D}$ in the field of herbal cosmetic to prove effectiveness and established herbal cosmetic in safety profile. It is needed to conduct adequate safety testing as per existing regulatory rule and present requirement. The ability to desire the right cosmetics for you depends on accurate ingredient knowledge, body Prakriti assessment, personal needs, customer perception about product, benchmark product. Quality control for ability and safety of herbal cosmetic products is of predominant importance. So quality control test must be carried out for herbal cosmetics. It is assumed to be safe for longer periods of time.

ACKNOWLEDGEMENT: The authors thankful with our deepest core of heart to Dr. Shashi Alok (Assistant Professor), for his valuable guidance.

\section{CONFLICT OF INTERST: Nil}

\section{REFERENCES:}

1. Hughes GR: J. Soc. Cosmet. Chem., 1959; X: 159.

2. Encyclopaedia. Britannica, Edition $14^{\text {th }}, 1929$.

3. Saha R: Cosmeceuticals and herbal drugs: practical uses. International Journal of Pharmaceutical Research and Sciences, 2012; 3: 59-65.

4. Sharma HD and Paramesh R: Trends in aging and skin care: Ayurvedic concepts. Journal of Ayurveda and Integrative Medicine, 2010; 1: 110-113.

5. Kapoor VP: Herbal Cosmetics for skin and hair care. Natural Product Radiance, 306-314. 
6. Sankholkar DS: Current Regulations and Suggested Way Forward, The Pharma Times, 2009; 41(8): 30-31.

7. Chaudhuri DK: Sc'F' andH, PCD 2006.

8. www.ayurvedic-herbal-products.com/herbalextracts.html

9. Gediya SK, Mistry RB, Patel UK, Blessy M and Jain HN: Herbal plants: Used as cosmetics. J. Nat Prod Plant Resour. 2011; 1: 24-32.

10. WHO guideline, 2000.

11. www.indo-world.com/cosmeticherbhistory.html

12. Top 7 Advantages of using Natural Cosmetics.

13. Akinyele BO and Odiyi AC: Comparative study of the vegetative morphology and the existing taxonomic status of Aloe vera. Journal of Plant Sciences, 2007; 2: 558-563.

14. Escamilla M, Ferre A, Hidalgo C, Fuentes N, Kaps R, et al., Revision of European ecolabel criteria for soaps, shampoos and hair conditioners. Joint Research Centre European Commission, 2012; 1-40.

15. Suzuki D: The "Dirty Dozen" ingredients investigated in the David Suzuki Foundation Survey of chemicals in cosmetics. Backgrounder, 2010; 1-15.

16. Occupational Exposure to Hazardous Agents.

17. International Agency for Research on Cancer (IARC) monographs on the evaluation of carcinogenic risks to humans, 1978; 17: 1-365.

18. Kadam VS, Chintale AG, Deshmukh KP and Nalwad DN: Cosmeceuticals an emerging concept: A comprehensive review. International Journal of Research in Pharmacy and Chemistry, 2013; 3: 308-316.

19. Winter RA: Consumers dictionary of cosmetic ingredients. Three Rivers press United states USA, Edition $7^{\text {th }}, 2009$.

20. Ayurvedic and Herbal Products.

21. Sharma A, Shanker C, Tyagi LK, Singh M and Rao CV: Herbal medicine for market potential in India: An overview. Academic Journal of Plant Sciences, 2008; 1: 26-36.

22. US: Food and Drug Administration, "Parabens".

23. Joshi LS and Pawar HA: Herbal cosmetics and cosmeceuticals: An overview, Nat Prod Chem Res., 2015; 3: 170 .

24. Jain NK: A textbook of Forensic pharmacy. Jain MK, Vallabh Prakashan, Delhi, India, Edition $7^{\text {th }}, 2007$.

25. Ligade VS and Udupa N: Pharmaceuticals, cosmeceuticals and neutraceuticals: An overview of Regulations. Career Publications, Edition $1^{\text {th }}, 2010$.

26. Dureja H, Kaushik D, Gupta M, Kumar V and Lather V: Cosmeceuticals: An emerging concept. Indian Journal of Pharmacology, 2005; 37: 155-159.

27. Trueb RM: The value of hair cosmetics and pharmaceuticals. Dermatology, 2001; 202: 275-82.

28. www.indo-world.com/cosmeticherbextracts.html

29. www.cosmetics.co.in/cosmetic-products.html

30. Maeda K and Arbutin FM: mechanism of its depigmenting action in human melanocyte culture. J. Pharmacol. Exp. Ther, 1996; 276: 765-769.

31. Rabasco AAM and Gonzalez RML: Lipids in pharmaceutical and cosmetic preparations. Grasasy Aceites, 2000; 51: 74-96.

32. Gediya SK, Mistry RB, Patel UK, Blessy M and Jain HN: Herbal plants: used as cosmetics. J Nat Prod Plant Resource, 2011; 1: 24-32.

33. Athar M and Syed MN: Taxonomic perspective of plant species yielding vegetable oils used in cosmetics and skin care products. African Journal of Biotechnology, 2005; 4: $36-44$

34. Kuroda $\mathrm{Y}$ and Hara Y: Anti-mutagenic and anticarcinogenic activity of tea polyphenols. Mutation Research/Reviews in Mutation 1999; 436: 69-97.
35. Gediya SK, Mistry RB, Patel UK, Blessy M, Jain HN: Herbal plants: used as cosmetics. J. Nat Prod Plant Resour. 2001; 1: 24-32.

36. Adhami VM, Mukhtar H, Ahmad N, Farrukh A and Yukihiko H: Tea polyphenols as cancer chemopreventive agents. T cell Biochem, 1995; S-22: 169-180.

37. Katiyar SK and Elmets CA: Green tea polyphenols skin protection and antioxidant (Review). Int J Oncol, 2001; 18: 1307-1313.

38. Mukhtar H, Katiyar SK and Agarwal R: Green tea and skin anti-carcinogenic effects. J Invest Dermatol, 1994; 102: 3-7.

39. Muley BP, Khadabadi SS and Banaase NB: Phytochemical constituents and pharmacological activities of Calendula officinalis Linn. (Asteraceae): A review. Trop J pharma Res, 2009; 8: 455-465.

40. Okoh OO, Sadimenko AP, Asekeen OT and Afolayan AJ: The effects of Drying on the chemical components of Essential oils of Caledula officinalis Linn. African J Biotechnol, 2008; 7: 1500-1502.

41. Athar M and Syed MN: Taxonomic perspective of plant species yielding vegetable oils used in cosmetics and skin care products African. Journal of Biotechnology, 2005; 4: 36-44.

42. Itami S, Kurata S, Sonoda $\mathrm{T}$ and Takayasu S: Characterization of 5 alpha-reductase in cultured human dermal papilla cells from beard and occipital scalp hair. J. Invest Dermatol. 1991; 96(1): 57-60.

http:/www.ayurvedic-herbal products.com/ herbalextracts. html

43. Ozkur MK, Bozkurt MS, Balabanli B, Aricioglu A, Ilter N, et al., The effects of EGB 761 on lipid peroxide leaves and superoxide dismutase activity in sunburn. Photodermatol photoimmunol photomd 2002; 18: 117-120.

44. Strube $M$ and Dragsted OL: Naturally occuring antitumourigens. Iv. Carotenoids except $\beta$-carotene, 1999.

45. Jain A, Dubey S, Gupta A, Kannojia P and Tomar V: Potential of herbs as cosmeceuticals. IJRAP, 2010; 1: 7177.

46. Dixit SN, Srivastava HS and Tripathi RD: Lawsone, The antifungal antibiotic from leaves of Lawsonia inermis and some aspects of its mode of action. Indian Phytopathol, 1980; 31: 131-133.

47. Brown RP, Gerbarg PL and Ramazanov Z: Rhodiola rosea: A phytomedical overview. Herbal Gram. The Journal of the American Botanical Council, 2002; 56: 4052.

48. Furmanowa M, Skopinska RE, Rogala E and Malgorzata $\mathrm{H}$ : Rhodiola rosea in-vitro culture: phytochemical analysis and antioxidant action. Acta Societis Botanicorum Poloniae, 1998; 67: 69-73

49. Chaudhary G, Goyal S and Poonia P: Lawsonia inermis Linnaeus: A phytopharmacological review. International Journal of Pharmaceutical Sciences and Drug Research, 2010; 2: 91-98.

50. Pandey S, Meshya N and Viral D: Herbs play an important role in the field of cosmetics. International Journal of Pharm Tech Research, 2010; 2: 632-639

51. Shuster S, Black MM and Mcvitie E: The influence of age and sex on skin thickness, skin collagen and density, Br. J. Dermatol. 1975; 93: 639-643.

52. Khanpara K, Renuka V, Shukla J and Harsha CR: A Detailed Investigation of shikakai (Acacia concinna Linn.) fruit. Journal of Current Pharmaceutical Research, 2012; 9: 06-10.

53. Aslam MN, Lansky EP and Varani J: Pomegranate as a cosmeceutical source: pomegranate fractions promote 
proliferation and procollagen synthesis and inhibit matrix metalloproteinase-1 production in human skin cells. J. Ethnopharmacol. 2006; 103: 311-318.

54. Tournas JA, Lin FH, Burch JA, et al., Ubiquinone, idebenone, and kinetin provide ineffective photoprotection to skin when compared to a topical antioxidant combination of Vitamins $\mathrm{C}$ and $\mathrm{E}$ with ferulic acid. $\mathrm{J}$ Invest Dermatol. 2006; 126: 1185-1187.

55. Craig WJ: Health-promoting properties of common herbs. Am J Clin Nutr. 1999; 70: 491S-499S.

56. Rao Diwan PV: Herbal formulation useful as therapeutic and cosmetic applications for the treatment of general skin disorders, 2001.US6200570 B1.

57. Marini JL: Cosmetic herbal compositions. 2007. EP182 5845

58. Mengoli F: Herbal cosmetic compsns-contg. Herbs in mixt of surfactants, essential oils, etc. 1993. DE4133085 A1,

59. Neelakantan K: Dry herbal, cleaning compositions, 1999. EP0908171 A1,

60. Bonte F, Dumas $\mathrm{M}$ and Maybeck A: Cosmetic or dermatologic composition containing at least one saponine of the ginsenoside type, and its applications particularly to hair care, 1994. WO1994006402 A2.

61. Kadam VS, Chintale AG, Deshmukh KP and Nalwad DN: Cosmeceuticals an emerging concept: A comprehensive Review. International Journal of Research in Pharmacy and Chemistry, 2013; 3: 308-316.

62. Barreto JC, Trevisan MTS, Hull WE, Erben G, De Brito ES and Pfundstein B: Characterization and quantitation of polyphenolic compounds in bark, kernel, leaves, and peel of mango (Mangifera indica L.). Journal of Agricultural and Food Chemistry 2008; 56(14): 5599-5610.

63. Scartezzini P and Speroni E: Review on some plants of Indian traditional medicine with antioxidant activity. $\mathrm{J}$ Ethnopharmacol 2000; 71: 23-43.

64. Cabral C, Francisco V, Cavaleiro C, Gonçalves MJ, Cruz MT and Sales F: Essential Oil of Juniperus communis subsp. alpina (Suter) Celak Needles: Chemical Composition, Antifungal Activity and Cytotoxicity. Phytotherapy Research 2012; 26(9): 1352-1357.

65. Melvina M, Dorothy G, Frank M, Joanne E, Margaret S and Cheryl S: Herbal Therapies and Diabetes among Navajo Indians. Diabetes Care 2005; 28(6): 1534-1535.

66. Anis E, Anis I, Ahmed S, Mustafa G, Malik A and Choudhary MI: Alpha-glucosidase inhibitory constituents from Cuscuta reflexa. Chem Pharm Bull 2002; 50(1): 112114.

67. Yang L, Chen Q, Wang F and Zhang G: Antiosteoporotic compounds from seeds of Cuscuta chinensis. J Ethnopharmacol 2011; 135(2): 553-560.

68. Habib-ur-Rehman, Yasin KA and Choudhary MA: Studies on the chemical constituents of Phyllanthus emblica. Nat. Prod. Res 2007; 21(9): 775-781.

69. Tiwari V, Kuhad A and Chopra K: Emblica officinalis corrects functional, biochemical and molecular deficits in experimental diabetic neuropathy by targeting the oxidonitrosative stress mediated inflammatory cascade. Phytotherapy Research 2011; 25(10): 1527-1536.

70. Sukanya DH, Lokesha AN, Datta G and Himabindu K: Phytochemical diversity in ashwagandha (Withania somnifera). Journal of Medicinal and Aromatic Plants 2010; 1(2): 27-30.

71. Mishra LC, Singh BB and Dagenais S: Scientific basis for the therapeutic use of Withania somnifera (Ashwagandha): A Review. Alternative Medicine Review 2000; 5(4): 3338.
72. Ruan B, Kong LY, Takaya Y and Niwa M: Studies on the chemical constituents of Psoralea corylifolia L. Journal of Asian Natural Products Research 2007; 9(1): 20-25.

73. Zhao G, Li S, Qin GW, Fei J and Guo LH: Inhibitive effects of Fructus Psoraleae extract on dopamine transporter and noradrenaline transporter. J Ethnopharmacol 2007; 112(3): 498-506.

74. Pino JA, Bayat F, Marbot R and Aguero J: Essential oil of Chamomilla recutita (Linn.) Rausch. J Essent Oil Res 2002; 14: 407-408.

75. Pirzad A, Alyari MR, Shaliba S, Zehtab-Salmasi and Moammadi A: Essential oil content and composition of German chamomile (Matricaria chamomilla L.) at different irrigation regimes. J Agron 2006; 5: 451-455.

76. Singh O, Khanam Z, Misra N and Srivastava MK: Chamomile (Matricaria chamomilla L.): An overview. Pharmacogn Rev 2011; 5(9): 82-95

77. Sang S, Lapsley K, Jeong WS, Lachance PA, Ho CT and Rosen RT: Antioxidative phenolic compounds isolated from almond skins (Prunus amygdalus Batsch). J. Agric. Food Chem 2002; 50(8): 2459-2463.

78. Esfahlan AJ, Jamei R and Esfahlan RJ: The importance of almond (Prunus amygdalus L.) and its by-products. Food Chemistry 2010; 120(2): 349-360.

79. Silva BM, Andrade PB, Ferreres F, Seabra RM, Oliveira $\mathrm{MB}$ and Ferreira MA: Composition of quince (Cydonia oblonga Miller) seeds: phenolics, organic acids and free amino acids. Nat Prod Res 2005; 19(3): 275-281.

80. Silva BM, Andrade PB, Valentao P, Ferreres F, Seabra RM and Ferreira MA: Quince (Cydonia oblonga Miller) Fruit (Pulp, Peel, and Seed) and Jam: Antioxidant activity. J. Agric. Food Chem 2004; 52(15): 4705-4712.

81. Sadhu SK, Khan MS, Ohtsuki $\mathrm{T}$ and Ishibashi M: Secoiridoid components from Jasminum grandiflorum. Phytochemistry 2007; 68(13): 1718-1721.

82. Chaturvedi AP and Tripathi YB: Methanolic extract of leaves of Jasminum grandiflorum Linn. modulates oxidative stress and inflammatory mediators. Inflammopharmacology 2011; 19(5): 273-281.

83. Zhang XH, da Silva JA, Jia YX, Zhao JT and Ma GH: Chemical composition of volatile oils from the pericarps of Indian sandalwood (Santalum album) by different extraction methods. Nat Prod Commun 2012; 7(1): 93-6.

84. Misra BB and Dey S: Evaluation of in-vivo antihyperglycemic and antioxidant potentials of $\alpha$-santalol and sandalwood oil. Phytomedicine 2013; 12: 17.

85. Misra BB and Dey S: Differential extraction and GC-MS based quantification of sesquiterpenoids from immature heartwood of East Indian sandalwood tree. Journal of Natural Sciences Research 2012; 2(6): 29-33.

86. Misra BB and Dey S: Shikimic acid (Tamiflu Precursor) production in suspension cultures of East Indian sandalwood (Santalum album) in Air-lift Bioreactor. Journal of Postdoctoral Research 2013; 1(1): 1-9.

87. Negi JS, Singh P and Rawat B: Chemical constituents and biological importance of Swertia: A review. Current Research in Chemistry, 2011; 3: 1-15.

88. Chen Y, Huang B, He J, Han L, Zhan Y and Wang Y: In vitro and in-vivo antioxidant effects of the ethanolic extract of Swertia chirayita. Journal of Ethnopharmacology 2011; 136(2): 309-315.

89. Liu Y, Murakami N, Ji H, Pedro A and Zhang S: Antimalarial flavonol glycosides from Euphorbia hirta. Pharm Biol 2007; 45: 278-281.

90. Williamson EM. Major herbs of Ayurveda. China: Churchill Livingstone; 2002. 
91. Ammar NM, Mohammed SH, Doha AM, Nabil EK, Ahmed HA and Tom JM: Phytochemical and biological studies of butea frondosa Roxb. leaves growing in Egypt. Medical Journal of Islamic World Academy of Sciences 2011; 19(4): 173-180.

92. Londonkar R and Ranirukmini RK: Anti-microbial activity of Butea frondosa Roxb. Journal of Pharmacognosy 2010; 1(1): 01-05

93. Lyantagaye SL: Ethnopharmacological and phytochemical review of Allium species (sweet garlic) and tulbaghia species (wild garlic) from southern Africa. Tanz. J. Sci 2011; 37: 17-21.

94. Gupta M, Biswas TK, Saha S and Debnath PK: Therapeutic utilization of secretory products of some Indian medicinal plants - A review. Indian Journal of Traditional Knowledge 2006; 5(4): 569-575.

95. Awasthi PK and Dixit SC: Chemical composition of Curcuma Longa leaves and rhizome oil from the plains of Northern India. Pharmacognosy 2009; 1(4): 312-316,

96. Prajapati MS, Patel JB, Modi K and Shah MB: Leucas aspera: A review. Pharmacogn Rev 2010; 4(7): 85-87.

97. Srinivasan R: Leucas Aspera - Medicinal plant: A review. International Journal of Pharma and Bio Sciences 2011; 2(1): 153-159.

98. Oudhia P: Kamala or kamopillaka (Mallotus philippinensis Muell.). Society for Parthenium Management (SOPAM) 2013.

99. Barreto JC, Trevisan MTS, Hull WE, Erben G, De Brito ES and Pfundstein B: Characterization and quantitation of polyphenolic compounds in bark, kernel, leaves, and peel of mango (Mangifera indica L.). Journal of Agricultural and Food Chemistry 2008; 56(14): 5599-5610.

100. Toshihiro A, Naoki H, Harukuni T, Motohiko U, Hiroyuki A and Yuichi T: Cucurbitane-type triterpenoids from the fruits of Momordica charantia and their cancer chemopreventive effects. Journal of Natural Products 2007; 70: 1233-1239.

101. Beloin N, Gbeassor M, Akpagana K, Hudson J, De Soussa $\mathrm{K}$ and Koumaglo K: Ethnomedicinal uses of Momordica charantia (Cucurbitaceae) in Togo and relation to its phytochemistry and biological activity. Journal of Ethnopharmacology 2005; 96(1-2): 49-55.

102. Shah AJ and Gilani AH: The Calcium channel blocking and Phosphodiesterase Inhibitory activities of the extract of Andropogon muricatus explains its medicinal use in airways disorders. Phytotherapy Research 2012; 26(8): 1256-1258,

103. Wu XY, Chao ZM, Wang C, Tan ZG and Sun W: Chemical constituents contained in fatty oil from seeds of Cucumis sativus. Zhongguo Zhong Yao Za Zhi 2012; 37(21): 3252-3255.

104. Yan XN, Sikora RA and Zheng JW: Potential use of cucumber (Cucumis sativus L.) endophytic fungi as seed treatment agents against root-knot nematode Meloidogyne incognita. J Zhejiang Univ Sci B 2011; 12(3): 219-225.

105. Zhang T, Wang H, Du G and Chen R: Study on chemical constituents from roots of Saussurea lappa. Zhongguo Zhong Yao Za Zhi 2009; 34(10): 1223-1224.

106. Zhang T, Ma L, Wu F and Chen R: Chemical constituents from a portion of ethanolic extract of Saussurea lappa roots. Zhongguo Zhong Yao Za Zhi 2012; 37(9): 12321236.

107. Jia JM, Wu CF, Liu W, Yu H, Hao Y and Zheng JH: Antiinflammatory and analgesic activities of the tissue culture of Saussurea involucrata. Biological and Pharmaceutical Bulletin 2005; 28(9): 1612-1614.
108. Zhang J, Yuan K, Zhou WL, Zhou J and Yang P: Studies on the active components and antioxidant activities of the extracts of Mimosa pudica Linn. from southern China. Pharmacogn Mag 2011; 7(25): 35-39.

109. Behera SK, Panda A and Misra MK: Medicinal plants used by the Kandhas of Kandhamal District of Orissa. Indian J Traditi Knowl 2006; 5: 519-528.

110. Apostolova EGK, Georgiev MI, Ilieva MP, Skibsted LH, Rodtjer A and Andersen ML: Extracts of plant cell cultures of Lavandula vera and Rosa damascena as sources of phenolic antioxidants for use in foods. European Food Research and Technology 2008; 227(4): 1243-1249.

111. Mostafavi A and Afzali D: Chemical composition of the essential oils of Rosa damascena from two different locations in Iran. Chemistry of Natural Compounds 2009; 45(1): 110-113.

112. Zuzarte MR, Dinis AM, Cavaleiro C, Salgueiro LR and Canhoto JM: Trichomes, essential oils and in-vitro propagation of Lavandula pedunculata (Lamiaceae). Industrial Crops and Products 2010; 32(3): 580-587.

113. Kundu $\mathrm{P}$ and lascar S: A brief resume on the genus Ailanthus: chemical and pharmacological aspects. Phytochemistry Reviews 2010; 9: 379-412

114. Suzuki R, Iijima M, Okada Y and Okuyama T: Chemical constituents of the style of Zea mays L. with glycation inhibitory activity. Chem Pharm Bull 2007; 55(1): 153155.

115. Negrotto D, Jolley M, Beer S, Wenck AR and Hansen G: The use of phosphomannose-isomerase as a selectable marker to recover transgenic maize plants (Zea mays L.) via Agrobacterium transformation. Plant Cell Reports 2000; 19(8): 798-803.

116. Yong JW, Ge L, Ng YF and Tan SN: The chemical composition and biological properties of coconut (Cocos nucifera L.) water. Molecules 2009; 14(12): 5144-5164.

117. Siddiqui S, Mahmood T, Faizi S and Siddiqui BS: Studies in the chemical constituents of Azadirachta indica A. Juss (Meliaceae). J. Chem. Soc 1987; 1: 1429-1432.

118. Kamal GM, Anwar F, Hussain AI, Sarri N and Ashraf MY: Yield and chemical composition of Citrus essential oils as affected by drying pretreatment of peels. International Food Research Journal 2011; 18(4): 12751282.

119. Molina EG, Perles RD, Moreno DA and Viguera CG: Natural bioactive compounds of Citrus limon for food and health. Journal of Pharmaceutical and Biomedical Analysis 2010; 51(2): 327-345

120. Chaurasia B, Dhakad RS, Dhakar VK and Jain PK: Preliminary phytochemical and pharmacological (Antidiabetic) screening of Cassia tora Linn. International Journal of Pharmacy and Life Sciences 2011; 2(5): 26-29.

121. Mazumder A, Lahkar V, Sahay J, Oraon A, Mazumder R and Pattnaik AK: Pharmacognostical studies on the leaves of Cassia tora Linn. (Fam. caesalpiniaceae). Anc Sci Life 2005; 25(2): 74-78

122. Quintal PC, Flores TG, Buenfil IR and Tintore SG: Antifungal activity in ethanolic extracts of Carica papaya $\mathrm{L}$. CV. maradol leaves and Seeds. Indian J Microbiol 2011; 51(1): 54-60.

123. Sadek KM: Antioxidant and immunostimulant effect of Carica papaya Linn. aqueous extract in acrylamide intoxicated rats. Acta Inform Med 2012; 20(3): 180-185

124. $\mathrm{Hu}$ YM, Ye WC, Yin ZQ and Zhao SX: Chemical constituents from flos Sesamum indicum L. Yao Xue Xue Bao 2007; 42(3): 286-291. 
125. Suja KP, Jayalekshmy A and Arumughan C: Free radical scavenging behavior of antioxidant compounds of sesame (Sesamum indicum L.) in DPPH system. J. Agric. Food Chem 2004; 52(4): 912-915

126. Hussain AI, Anwar F, Sherazi STH and Przybylski R: Chemical composition, antioxidant and antimicrobial activities of basil (Ocimum basilicum) essential oils depends on seasonal variations. Food Chemistry 2008; 108(3): 986-995.

127. Prakash P and Gupta N: Therapeutic uses of Ocimum sanctum Linn. (Tulsi) with a note on eugenol and its pharmacological actions: a short review. Indian J Physiol Pharmacol 2005; 49(2): 125-131

128. Khare CP: Encyclopedia of Indian medicinal plants. Berlin Heidelberg, Germany: Springer-Verlag; 2005: 372.

129. Tripathi P, Kumar R, Sharma AK, Mishra A and Gupta R: Pistia stratiotes (Jalkumbhi). Pharmacogn Rev 2010; 4(8): 153-160.

130. Singh TP, Singh OM and Singh HB: Adhatoda vasica Nees: Phytochemical and Pharmacological Profile. The Natural Products Journal 2011; 1(29): 29-39

131. https://www.newdirectionsaromatics.com/products/botanic al-extracts/

132. Zhang LZ, Zhao WH, Guo YJ, Tu GZ, Lin S and Xin LG: Studies on chemical constituents in fruits of Tibetan medicine Phyllanthus emblica. Zhongguo Zhong Yao Za Zhi 2003; 28(10): 940-943.

133. Krishnaveni M and Mirunalini S: Therapeutic potential of Phyllanthus emblica (Amla): the Ayurvedic wonder. J Basic Clin Physiol Pharmacol 2010; 21(1):

134. Venkatachalam M and Sathe SK: Chemical composition of selected edible nut seeds. J. Agric. Food Chem 2006; 54(13): 4705-4714.

135. Gaur RD: Traditional dye yielding plants of Uttarakhand, India. Natural Product Radiance 2008; 7(2): 2734-2739.

136. Judzentiene A and Budiene J: Analysis of the chemical composition of flower essential oils from Arnica montana of Lithuanian origin. chemija 2009; 20(3): 190-194.

137. Knuesel O, Weber M and Suter A: Arnica montana gel in osteoarthritis of the knee: An open, multicenter clinical trial. Advances in Therapy 2002; 19(5): 209-218

138. http://www.naturallivingideas.com/best-herbs-for-hairgrowth/

139. Paaver U, Orav A, Arak E, Mäeorg U and Raal A: Phytochemical analysis of the essential oil of Thymus serpyllum L. growing wild in Estonia. Nat Prod Res 2008; 22(2): 108-115.

140. Jaric S, Popovic Z, Jocic MM, Djurdjevic L, Mijatovic M and Karadzic B: An ethnobotanical study on the usage of wild medicinal herbs from Kopaonik Mountain (Central Serbia). Journal of Ethnopharmacology 2007; 111(1): 160175 .

141. Ahmed F and Urooj A: Traditional uses, medicinal properties, and phytopharmacology of Ficus racemosa: a review. Pharmaceutical Biology 2010; 48(6): 672-81.

142. Paarakh K and Padmaa M: Ficus racemosa Linn.-An overview. Natural product radiance 2009; 8(1): 84-90.

143. Oliveira JTA, Vasconcelos IM, Bezerra LCNM, Silveira SB, Monteiro ACO and Moreira RA: Composition and nutritional properties of seeds from Pachira aquatica Aubl, Sterculia striata St Hil et Naud and Terminalia catappa Linn. Food Chemistry 2000; 70(2): 185-191.

144. Misra M: Modern drug development from traditional medicinal plants using radioligand receptor-binding assays. Medicinal Research Reviews 1998; 18(6): 383-402

145. Oksanen E, Riikonen J, Kaakinen S, Holopainen T and Vapaavuori E: Structural characteristics and chemical composition of birch (Betula pendula) leaves are modified by increasing $\mathrm{CO}_{2}$ and ozone. Global Change Biology 2007; 11(5): 305-310.

146. Rytter L, Ericsson T and Rytter RM: Effects of demanddriven fertilization on nutrient use, root: Plant ratio and field performance of Betula pendula and Picea abies. Scandinavian Journal of Forest Research 2003; 18 (5): 225-229.

147. Ali Z and Khan IA: Chemical constituents of Terminalia chebula. Planta Med 2009; 75: 41.

148. Hsouna AB, Trigui M, Culioli G, Blache Y and Jaoua S: Antioxidant constituents from Lawsonia inermis leave: Isolation, structure elucidation and antioxidative capacity. Food Chemistry 2011; 125(1): 193-200.

149. Siddiqui BS, Kardar MN, Ali ST and Khan S: Two new and a known compound from Lawsonia inermis. Helvetica Chimica Acta 2003; 86(6): 2164-9.

150. Makhija IK: Lawsonia Inermis - from traditional use to scientific assessment. Pharma Tutor Pharmacy Infopedia 2010.

151. Gottumukkala VR, Annamalai T and Mukhopadhyay T: Phytochemical investigation and hair growth studies on the rhizomes of Nardostachys jatamansi DC. Pharmacogn Mag 2011; 7(26): 146-150.

152. Amatya G and Sthapit VM: A Note on Nardostachys jatamansi. Journal of Herbs, Spices and Medicinal Plants 1994; 2(2): 39-47

153. Zhang T, Wang H, Du G and Chen R: Study on chemical constituents from roots of Saussurea lappa. Zhongguo Zhong Yao Za Zhi 2009; 34(10): 1223-1224.

154. Zhang T, Ma L, Wu F and Chen R: Chemical constituents from a portion of ethanolic extract of Saussurea lappa roots. Zhongguo Zhong Yao Za Zhi 2012; 37(9): 12321236.

155. Jia JM, Wu CF, Liu W, Yu H, Hao Y and Zheng JH: Antiinflammatory and analgesic activities of the tissue culture of Saussurea involucrata. Biological and Pharmaceutical Bulletin 2005; 28(9): 1612-1614.

156. Chalchat JC, Garry RP and Michet A: Chemical composition of essential oil of Calendula officinalis L. (pot marigold). Flavour and Fragrance Journal 2010; 6(3): 316-20.

157. Calendula officinalis - L. Plants for a Future. 2007; 12-9

158. Miean KH and Mohamed S: Flavonoid (myricetin, quercetin, kaempferol, luteolin, and apigenin) content of edible tropical plants. J. Agric. Food Chem 2001; 49(6): 3106-3112.

159. Breeding Better Broccoli: research points to pumped up lutein levels in broccoli. Science Daily 2010.

160. Yong JW, Ge L, Ng YF and Tan SN: The chemical composition and biological properties of coconut (Cocos nucifera L.) water. Molecules 2009; 9; 14(12): 5144-5164.

161. Singla RK: Review on the pharmacological properties of Cocos nucifera Endocarp. Pharmaceutical Sciences 2012; 3(5): 278-284

162. Sinha RK, Majumdar K and Sinha S: Somatic embryogenesis and plantlet regeneration from leaf explants of Sapindus mukorossi Gaertn: a soapnut tree. Current Science 2000; 78(5): 620-623.

163. Oliveira JTA, Vasconcelos IM, Bezerra LCNM, Silveira SB, Monteiro ACO and Moreira RA: Composition and nutritional properties of seeds from Pachira aquatica Aubl, Sterculia striata St Hil et Naud and Terminalia catappa Linn. Food Chemistry 2000; 70(2): 185-191.

164. Zhi ZY, Huan C, Li Q, Fang HD, Ming HH and Hu PY: Chemical constituents from Carthamus tinctorius L. Chinese Journal of Medicinal Chemistry 2007; 06: 34-37. 
165. Bassil ES and Kaffka SR: Response of safflower (Carthamus tinctorius L.) to saline soils and irrigation: I. Consumptive water use. Agricultural Water Management 2002; 54(1): 67-80.

166. Oniga I, Oprean R, Toiu A and Benedec D: Chemical composition of the essential oil of Salvia officinalis L. from Romania. Rev Med Chir Soc Med Nat Iasi 2010; 114(2): 593-595.

167. Miura K, Kikuzaki H and Nakatani N: Antioxidant activity of chemical components from sage (Salvia officinalis L.) and Thyme (Thymus vulgaris L.) measured by the oil stability index method. J. Agric. Food Chem 2002; 50(7); 1845-1851.

168. Bozin B, Dukic NM, Samojlik I and Jovin E: Antimicrobial and antioxidant properties of rosemary and sage (Rosmarinus officinalis L. and Salvia officinalis L.,
Lamiaceae) essential oils. J. Agric. Food Chem 2007; 55(19): 7879-7885.

169. Mutai C, Abatis D, Vagias C, Moreau D, Roussakis C and Roussis V: Cytotoxic lupane-type triterpenoids from Acacia mellifera. Phytochemistry 2004; 65(8): 1159-1164.

170. Karanth KD: Forest use and human-wildlife conflicts in Bhadra Wildlife Sanctuary. Tropical Resources: Bulletin of the Yale Tropical Resources Institute, India, Karnataka. 2003; 22: 48-58.

171. Hu YM, Ye WC, Yin ZQ and Zhao SX: Chemical constituents from flos Sesamum indicum L. Yao Xue Xue Bao 2007; 42(3): 286-291.

172. Suja KP, Jayalekshmy A and Arumughan C: Free Radical scavenging behavior of antioxidant compounds of sesame (Sesamum indicum L.) in DPPH system. J. Agric. Food Chem 2004; 52(4): 912-915.

How to cite this article:

Bijauliya RK, Alok S, Kumar M, Chanchal DK and Yadav S: A comprehensive review on herbal cosmetics. Int J Pharm Sci Res 2017; 8(12): 4930-49.doi: 10.13040/IJPSR.0975-8232.8(12).4930-49.

All @ 2013 are reserved by International Journal of Pharmaceutical Sciences and Research. This Journal licensed under a Creative Commons Attribution-NonCommercial-ShareAlike 3.0 Unported License.

This article can be downloaded to ANDROID OS based mobile. Scan QR Code using Code/Bar Scanner from your mobile. (Scanners are available on Google Playstore) 